\title{
Aplikasi Musicroid sebagai Media Pembelajaran Seni Musik Berbasis Android
}

\author{
Adi Purwanto, Ida Widaningrum*, Khoiru Nurfitri \\ Program Studi Informatika \\ Universitas Muhammadiyah Ponorogo \\ Ponorogo \\ *iwidaningrum.as@gmail.com
}

\begin{abstract}
Abstrak-Musik merupakan salah satu cabang seni yang telah lama ada di dunia. Musik membuat hidup ini semakin berwarna, kemanapun dan di manapun tanpa kita sadari berdampingan dengan musik. Penelitian ini adalah tentang media pembelajaran yang menarik untuk pembelajaran seni musik, terutama gitar dan piano untuk membantu siswa yang kesulitan memahami konsep chord dan cara memainkannya. Chord Theory perlu dipahami siswa karena menjadi dasar permainan alat musik. Penelitian ini menggunakan model ADDIE, yang meliputi 5 tahapan yaitu: Analysis, Design, Development, Implementation, dan Evaluation. Pengembangan media pembelajaran seni musik ini disebut "Musicroid". Musicroid menggunakan sistem Android yang saat ini dikenal sebagai sistem operasi Open Source. Pengembangan dilakukan dengan menggunakan software Android Studio yang didukung dengan pemrograman bahasa Java. Hasil yang diperoleh dari hasil uji validasi ahli materi dengan nilai 4,6 dan ahli media dengan nilai 4,3 termasuk kategori sangat layak. Uji kelayakan faktor usability memperoleh nilai 5,8, dikategorikan sangat layak sebagai media pembelajaran musik.
\end{abstract}

Kata kunci: Musicroid, Media Pembelajaran, ADDIE, Android Studio, Java

\section{Pendahuluan}

Musik merupakan salah satu cabang seni yang telah lama ada di dunia dan membuat hidup semakin berwarna. Tidak bisa dipungkiri bahwa musik juga mengubah gaya hidup manusia zaman sekarang. Pendidikan musik telah mengalami perkembangan yang sangat pesat hingga berbagai metode pembelajaran dalam musik pun ikut berinovasi. Media pembelajaran mobile learning menggunakan smartphone sangat bervariasi dan menarik, sehingga kita dapat berlama-lama mempelajari materi yang tersedia di dalam aplikasi tersebut.

Media pembelajaran harus dikemas semenarik mungkin agar siswa bisa dengan nyaman memahaminya. Media pembelajaran bisa berupa aplikasi Musicroid yang di-install pada smartphone siswa. Pelajaran musik biasanya diberikan pada siswa SMKN yang dikemas dalam mata pelajaran Seni Budaya, khususnya Seni Musik. Pada pembelajaran konvensional, guru menguraikan materi di depan kelas tanpa adanya media apapun kemudian memberikan tugas pada siswa dengan materi yang sangat terbatas. Dalam pembelajaran Seni Budaya khususnya Seni Musik ini, lebih ditekankan pada materi praktik yang meliputi permainan chord dengan tangga nada yang berbeda dalam lagu. Dengan sistem pembelajaran demikian, siswa akan merasa kesulitan karena banyak sekali chord theory yang belum dapat mereka pelajari. Oleh karena itu dirasa akan lebih baik apabila dibuat sistem atau aplikasi yang dapat mengatasi hal tersebut.

Beberapa penelitian sebelumnya tentang pembelajaran musik di antaranya adalah menggunakan audio visual [1]. Di sini disebutkan bahwa media audio visual dapat memberikan dampak positif pada proses dan hasil belajar siswa. Selain itu dengan aplikasi media pembelajaran piano memanfaatkan augmented reality, siswa dapat belajar lebih mudah dan menyenangkan[2]. Penelitian selanjutnya adalah pengembangan aplikasi pembelajaran interaktif teknik bermain piano berbasis multimedia, yang bisa memotivasi siswa untuk belajar piano [3].

Ada beberapa aplikasi di PlayStore yang mengajarkan cara mempelajari musik, contohnya Music Trainer Profesional karya Martin. Pada aplikasi ini terdapat berbagai teori tentang musik khususnya notasi balok menggunakan bahasa Inggris, tetapi masih agak sulit untuk dipahami. Musicdroid adalah bagian dari Proyek Catrobat dan merupakan aplikasi Android untuk membuat musik [4]. Catrobat adalah bahasa pemrograman visual dan seperangkat alat kreativitas open source (FOSS/free open source software) untuk menampilkan sesuatu dengan cara yang menyenangkan dan menarik [5][6]. 
Berdasarkan penelitian terdahulu yang sudah diuraikan di atas sudah banyak media pembelajaran musik, tetapi belum ada media yang mengupas secara tuntas pembelajaran musik yang terdiri dari sejarah musik, notasi, chord, video pembelajaran, kuis yang bisa digunakan untuk mengukur sejauh mana pengetahuan siswa tentang musik. Selain itu juga belum ada media pembelajaran yang disesuaikan dengan kompetensi dasar untuk siswa SMK. Sehingga pada penelitian ini dibuat aplikasi Musicroid. Aplikasi Musicroid ini mengacu pada materi dasar yang diperlukan siswa untuk belajar memainkan alat musik. Dalam aplikasi ini tersedia chord guitar theory, chord piano theory, tutorial bagaimana cara membaca notasi balok serta adanya video-video pembelajaran di dalamnya yang terintegrasikan langsung dengan Channel Youtube pengembang.

\section{Metode}

Media adalah segala sesuatu yang dapat digunakan untuk mencapai tujuan pengajaran [7]. Media pembelajaran adalah alat bantu apa saja yang dapat dijadikan sebagai penyalur pesan agar tercapai tujuan pembelajaran [8][9] [10]. Sedangkan Android adalah sistem operasi bergerak (mobile operating system) yang mengadopsi operating system Linux, namun telah dimodifikasi [11]. System Android bersifat open source sehingga banyak sekali programmer yang beralih ke Android dan dapat dengan mudah mengembangkannya [12].

Pengembangan aplikasi Musicroid sebagai media pembelajaran ini menggunakan metode penelitian dan pengembangan (research and development) [13]. Research and development pada hal ini dapat diartikan penelitian dan pengembangan yang bertujuan untuk menghasilkan suatu produk baru dari sebuah proses pengembangan. Dalam penelitian ini, produk yang dihasilkan adalah software Musicroid yaitu aplikasi belajar musik yang berbasis Android dengan target pengembangannya adalah para siswa. Untuk mendapatkan hasil dan produk yang layak, digunakan pengembangan perangkat pembelajaran ADDIE yang terdiri dari analysis, design, development, implementation, dan evaluation [14][15][16]. ADDIE adalah konsep pengembangan yang digunakan untuk membangun pembelajaran berbasis kinerja (constructing performance-based learning). Filosopi pendidikan ADDIE adalah pembelajaran harus berpusat pada siswa, inovatif, otentik dan inspirasional, sangat sesuai untuk mengembangkan produk pendidikan dan sumber belajar lainnya.

Tahap analisis, dilakukan analisis terhadap masalah yang ada melalui wawancara, survei, studi literatur, dan surf di dunia maya. Selain itu, juga dilakukan analisis terhadap Kompetensi Dasar (KD) musik untuk siswa SMK [17]. Hal ini dapat menambah manfaat atau pun kelayakan produk yang dibuat.

Tahap desain, yaitu menentukan komponenkomponen apa saja yang akan digunakan dalam pengembangan media pembelajaran guna menambah detail dari aplikasi Musicroid. Mulai dari pembuatan desain media pembelajaran (storyboard) yang menjadi gambaran secara keseluruhan dari media pembelajaran ini. Menetapkan materi yang akan dimuat dalam aplikasi meliputi Chord Theory piano dan gitar [15]-[20], sejarah musik [22][23][24], dan cara membaca notasi balok dasar serta dilakukan pengkajian materi sesuai dengan kurikulum dan melakukan pengumpulan aset yang berupa background, font, gambar, hingga video materi.

Tahap pengembangan membuat produk media pembelajaran seni musik berbasis android sesuai dengan format yang telah ditentukan menggunakan IDE Android Studio lalu melakukan validasi dari ahli media dan ahli materi guna mendapatkan saran, masukan dan komentar yang dapat digunakan sebagai dasar pengembangan yang lebih baik lagi.

Tahap implemetasi pada penelitian ini adalah uji coba yang dilakukan terhadap aplikasi Musicroid melalui para siswa kelas XI SMKN 2 Ponorogo dan disertai pembagian angket kuesioner guna untuk mengetahui kelayakan dari produk yang telah dihasilkan untuk dapat masuk dalam proses yang terakhir, yaitu evaluasi.

Tahap evaluasi harus dilalui agar bisa mengetahui apakah aplikasi yang dibuat sudah sesuai dengan yang diharapkan [25]. Untuk melihat kesesuaian pembelajaran ini dengan kisi-kisi materi yang harus ditempuh siswa, maka harus dilakukan uji validasi aspek media dan materi. Materi yang diuji terdiri dari kualitas dan kelayakan media pembelajaran, yang merupakan aspek relevansi materi, aspek pengorganisasian materi, aspek evaluasi, bahasa, tampilan visual, rekayasa perangkat lunak, dan aspek strategi pembelajaran [26][27]. Uji validasi ini terbagi menjadi dua yaitu untuk ahli media seperti pada Tabel 1 , dan ahli materi (Tabel 2).

Tabel 1. Kisi-Kisi Instrumen untuk Ahli Media

\begin{tabular}{|c|c|c|c|}
\hline Aspek & Indikator & Butir & Soal \\
\hline \multirow{5}{*}{$\begin{array}{l}\text { Rekayasa } \\
\text { Perangkat } \\
\text { Lunak }\end{array}$} & Efisiensi panduan & 2 & 1,2 \\
\hline & Kehandalan panduan (reliable) & 2 & 3,4 \\
\hline & $\begin{array}{l}\text { Ketepatan penggunaan } \\
\text { panduan }\end{array}$ & 2 & 5,6 \\
\hline & $\begin{array}{l}\text { Ketepatan pemilihan software/ } \\
\text { tool untuk pengembangan }\end{array}$ & 2 & 7,8 \\
\hline & Pemaketan program panduan & 2 & 9,10 \\
\hline \multirow{7}{*}{$\begin{array}{l}\text { Komunikasi } \\
\text { Visual }\end{array}$} & Komunikatif & 2 & 11,12 \\
\hline & $\begin{array}{l}\text { Kreatif dalam gagasan dan } \\
\text { ide }\end{array}$ & 2 & 13,14 \\
\hline & $\begin{array}{l}\text { Tampilan sederhana dan } \\
\text { memikat }\end{array}$ & 2 & 15,16 \\
\hline & Penggunaan visual & 2 & 17,18 \\
\hline & Pemilihan warna & 2 & 19,20 \\
\hline & Pemilihan jenis huruf & 2 & 21,22 \\
\hline & $\begin{array}{l}\text { Layout interaktif (ikon } \\
\text { navigasi) }\end{array}$ & 2 & 23,24 \\
\hline
\end{tabular}


Tabel 2. Kisi-Kisi Instrumen untuk Ahli Materi

\begin{tabular}{llcc}
\hline \multicolumn{1}{c}{ Aspek } & \multicolumn{1}{c}{ Indikator } & Butir & Soal \\
\hline \multirow{2}{*}{$\begin{array}{l}\text { Kebenaran } \\
\text { Konsep }\end{array}$} & $\begin{array}{l}\text { Kejelasan tujuan } \\
\text { pembelajaran }\end{array}$ & 2 & 1,2 \\
& $\begin{array}{l}\text { Kebenaran materi ditinjau } \\
\text { dari aspek keilmuan }\end{array}$ & 2 & 3,4 \\
& Penggunaan bahasa & 2 & 5,6 \\
& Kesesuaian materi & 2 & 7,8 \\
Penyusunan & Kedalaman materi & 2 & 9,10 \\
Materi & Kontekstualitas & 2 & 11,12 \\
& Kelengkapan bahan & 2 & 13,14 \\
& pendukung materi & & \\
Potensi & Kemudahan materi untuk & 2 & 15,16 \\
Keterlaksanaan & Aluhami logika yang jelas & 2 & 17,18 \\
& Interaktivitas & 2 & 19,20 \\
\hline
\end{tabular}

Tabel 3. Storyboard Aplikasi Musicroid

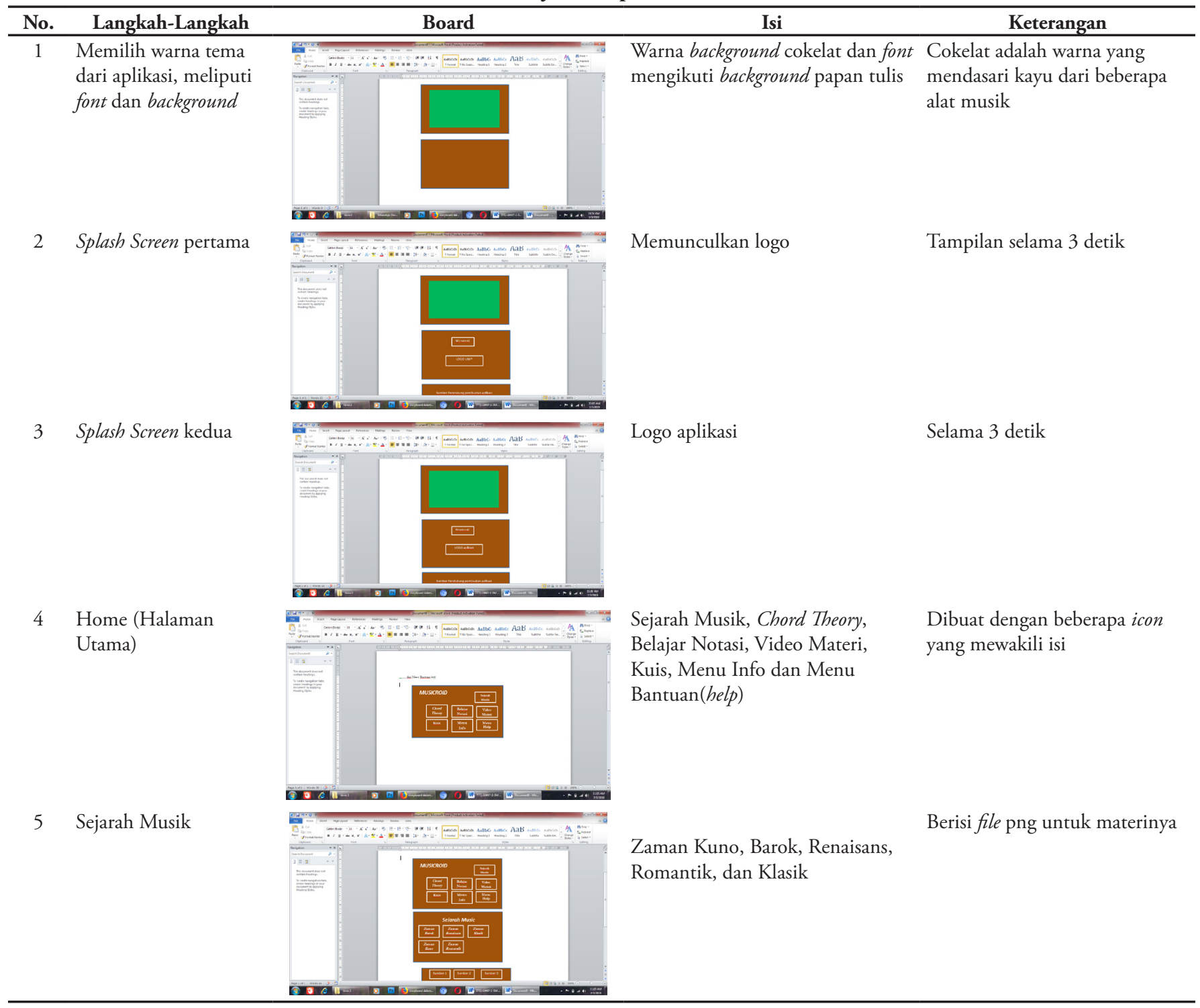




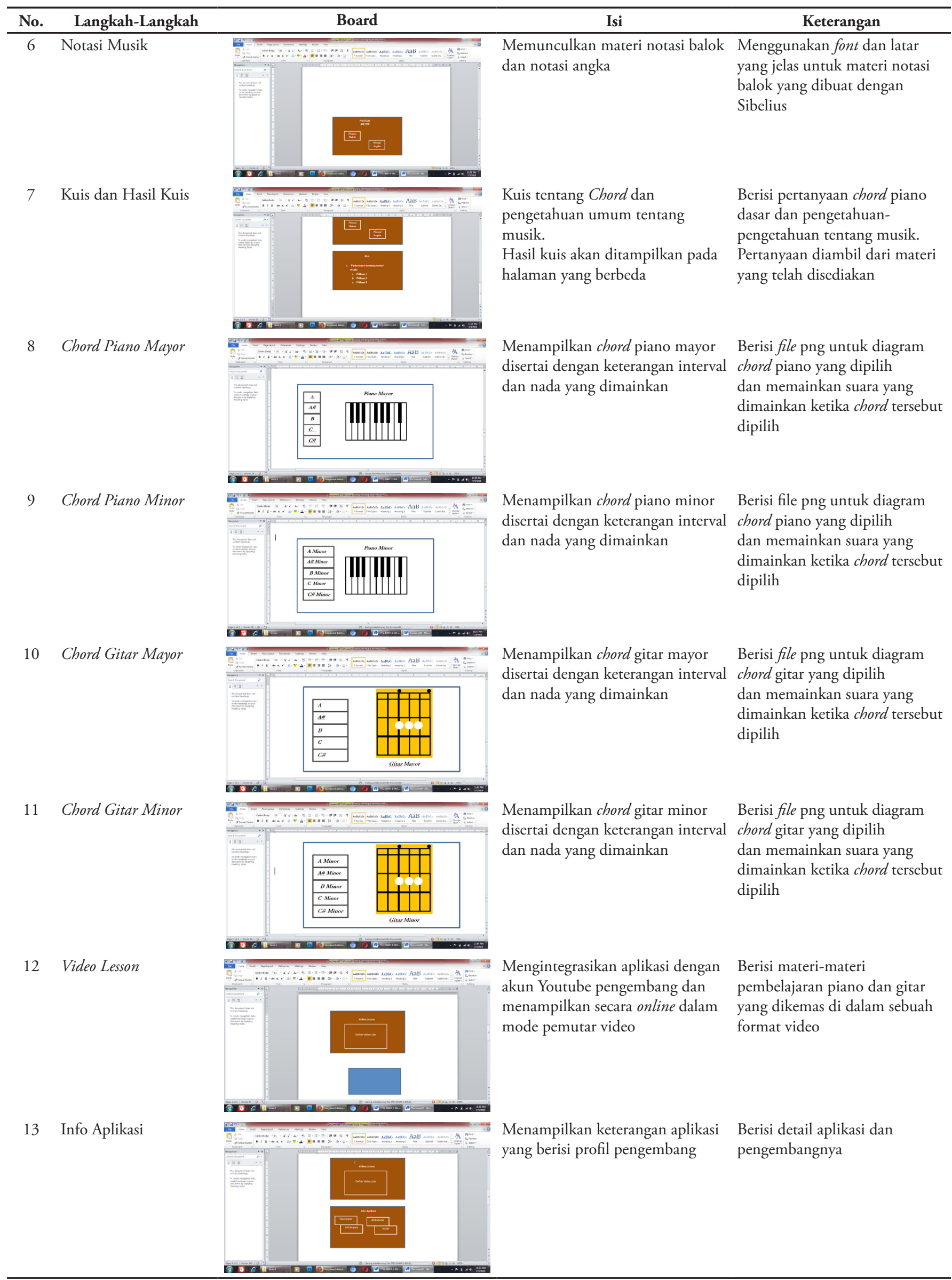




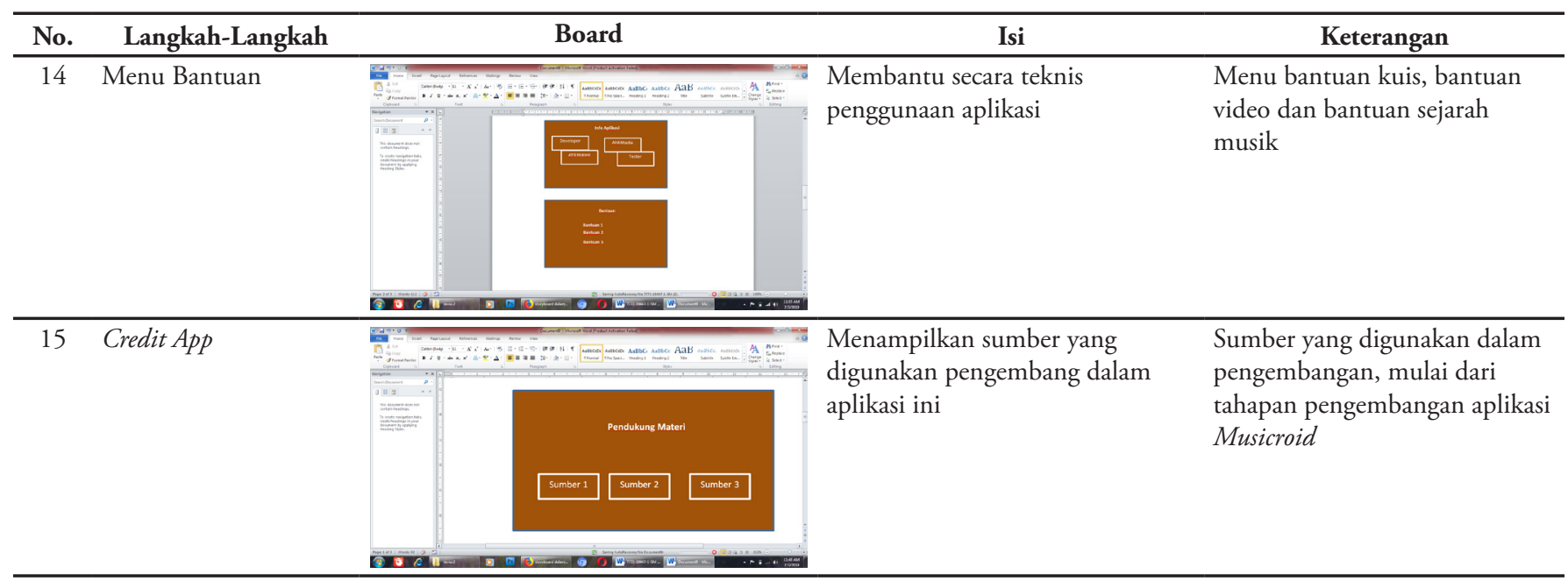

Berikut adalah storyboard dari aplikasi yang akan dibuat untuk memetakan konsep kebutuhan media pembelajaran (Tabel 3). Rancangan produk Musicroid terdiri dari: Splash Screen, merupakan tampilan awal yang menyambut pengguna pada saat awal aplikasi dijalankan. Halaman splash ini, menampilkan logo dan loading dari aplikasi. Home screen, adalah tampilan utama yang merupakan sebuah peta konsep yang mendasari materimateri yang ada di dalam aplikasi media pembelajaran Musicroid ini. Selanjutnya halaman sejarah musik, merupakan tampilan yang akan membawa kita untuk memilih sejarah pada zaman apa yang akan kita pelajari. Sejarah musik mulai dari zaman kuno, zaman renaisans, zaman barok, zaman romantic, dan zaman klasik. Notasi Musik, halaman yang membawa kita untuk mempelajari cara membaca notasi balok secara sederhana dan mendasar. Kuis dan hasil kuis, merupakan sebuah pengayaan dari tentang materi yang telah dipelajari melalui aplikasi ini. Chord theory adalah halaman yang menyediakan beberapa jenis chord mulai dari chord mayor piano, chord minor piano, chord mayor gitar, dan chord minor gitar. Video lesson ini menyediakan materi berupa video yang meliputi piano penjarian dasar, permainan lagu, pengenalan tangga nada pada piano dan gitar, penjarian dasar pada gitar serta cara bermain gitar dengan teknik strumming. Tampilan info atau tentang yang menyajikan informasi mengenai detail aplikasi Musicroid sebagai media pembelajaran seni musik berbasis Android. Credits App yang akan menampilkan sumber materi, sumber gambar, dan inspirasi yang telah dimuat di dalam aplikasi.

Subjek penelitian ini adalah satu ahli materi dan satu ahli media serta melibatkan 20 siswa anggota dari band di salah satu SMKN di Ponorogo. Guna mengetahui kelayakan produk Musicroid sebagai media pembelajaran seni musik, maka dilakukan beberapa uji kelayakan dan sebagai objeknya yaitu pengembangan aplikasi Musicroid sebagai media pembelajaran seni musik di SMKN 2 Ponorogo dengan memanfaatkan teknologi berbasis Android yang sebelumnya masih menggunakan metode pembelajaran secara konvensional.
Skor yang telah didapatkan lalu dikonversi menjadi nilai melalui rumus skala dengan rentang nilai seperti yang dinyatakan dalam Tabel 4 [25]:

Tabel 4. Konversi Skala Skor Menjadi Nilai

\begin{tabular}{ll}
\hline \multicolumn{1}{c}{ Kriteria } & \multicolumn{1}{c}{ Rentang Nilai } \\
\hline Sangat Layak & $>\mathrm{Mi}+1,5 \mathrm{SBi}$ \\
Layak & $\mathrm{Mi}+0,5 \mathrm{SBi}<\mathrm{s.d}<\mathrm{Mi}+1,5 \mathrm{SBi}$ \\
Cukup & $\mathrm{Mi}-0,5 \mathrm{SBi}<\mathrm{s.d}<\mathrm{Mi}+0,5 \mathrm{SBi}$ \\
Kurang Layak & $\mathrm{Mi}-1,5 \mathrm{SBi}<\mathrm{s.d}<\mathrm{Mi}-0,5 \mathrm{SBi}$ \\
$\begin{array}{l}\text { Sangat Kurang } \\
\text { Layak }\end{array}$ & $<\mathrm{Mi}-1,5 \mathrm{SBi}$ \\
\hline
\end{tabular}

Dengan:

Mi $($ Rata-rata ideal $)=1 / 2 \times($ skor maksimal + skor minimal $)$ $\mathrm{SBi}($ Simpang Baku Ideal) $=1 / 6 \times$ (skor maksimal-skor minimal)

Analisis data responden dilakukan untuk pengguna dalam hal ini siswa yang akan menggunakan aplikasi tersebut. Instrumen angket untuk responden atau user akan menggunakan kuesioner dengan interval skor dari 1 sampai 7 dan digunakan untuk aspek usability (tabel 5) [28][29].

Tabel 5. Instrumen Kuesioner untuk Responden Pengguna

\begin{tabular}{cll}
\hline No. & \multicolumn{1}{c}{ Pertanyaan } & Skor Penilaian \\
\hline 1. & $\begin{array}{l}\text { Secara keseluruhan, saya puas dengan } \\
\text { kemudahan dalam menggunakan } \\
\text { aplikasi ini }\end{array}$ & \\
2. & $\begin{array}{l}\text { Cara menggunakan aplikasi ini } 123567 \\
\text { sederhana }\end{array}$ \\
3. & $\begin{array}{l}\text { Saya dapat belajar secara efektif dengan } \\
\text { menggunakan aplikasi ini }\end{array}$ & 1234567 \\
4. & $\begin{array}{l}\text { Saya dapat belajar dengan cepat } \\
\text { menggunakan aplikasi ini }\end{array}$ \\
5. & $\begin{array}{l}\text { Saya bisa efisien belajar dengan } \\
\text { menggunakan aplikasi ini }\end{array}$ & 1234567 \\
\hline
\end{tabular}




\begin{tabular}{|c|c|c|}
\hline No. & Pertanyaan & Skor Penilaian \\
\hline 6. & $\begin{array}{l}\text { Saya merasa nyaman menggunakan } \\
\text { aplikasi ini }\end{array}$ & 1234567 \\
\hline 7. & Aplikasi ini mudah dipelajari & 1234567 \\
\hline 8. & $\begin{array}{l}\text { Saya percaya saya lebih produktif } \\
\text { dengan menggunakan aplikasi ini }\end{array}$ & 1234567 \\
\hline 9. & $\begin{array}{l}\text { Sistem ini memberikan pilihan } \\
\text { bantuan yang jelas, memberitahu saya } \\
\text { bagaimana menjalankan aplikasi }\end{array}$ & 1234567 \\
\hline 10. & $\begin{array}{l}\text { Setiap kali saya melakukan kesalahan, } \\
\text { saya pulih dengan mudah dan cepat }\end{array}$ & 1234567 \\
\hline 11. & $\begin{array}{l}\text { Informasi yang disediakan dengan } \\
\text { aplikasi ini jelas }\end{array}$ & 1234567 \\
\hline 12. & $\begin{array}{l}\text { Sangat mudah untuk menemukan } \\
\text { informasi yang saya butuhkan }\end{array}$ & 1234567 \\
\hline 13. & $\begin{array}{l}\text { Informasi yang diberikan aplikasi } \\
\text { mudah dimengerti }\end{array}$ & 1234567 \\
\hline 14. & $\begin{array}{l}\text { Informasi ini efektif dalam membantu } \\
\text { saya belajar }\end{array}$ & 1234567 \\
\hline 15. & $\begin{array}{l}\text { Tata letak informasi yang terdapat di } \\
\text { layar aplikasi terlihat jelas }\end{array}$ & 1234567 \\
\hline 16. & Tampilan aplikasi ini menyenangkan & 1234567 \\
\hline 17. & $\begin{array}{l}\text { Saya suka menggunakan tampilan } \\
\text { aplikasi semacam ini }\end{array}$ & 1234567 \\
\hline 18. & $\begin{array}{l}\text { Aplikasi ini memiliki semua fungsi } \\
\text { dan kemampuan yang saya butuhkan }\end{array}$ & 1234567 \\
\hline 19. & $\begin{array}{l}\text { Secara keseluruhan, saya puas dengan } \\
\text { aplikasi ini }\end{array}$ & 1234567 \\
\hline
\end{tabular}

Analisis data responden atau users ini diambil dengan langkah menghitung rentang penilaian, menentukan kriteria penilaian dan mencari rata-rata skor data per item.

\section{Hasil dan pembahasan}

Hasil yang dicapai dari penelitian ini adalah sebuah produk aplikasi Musicroid sebagai media pembelajaran seni musik dengan memanfaatkan teknologi berbasis Android. Aplikasi media pembelajaran ini dikembangkan menggunakan laptop dengan spesifikasi harddisk $500 \mathrm{~GB}$, RAM 6 GB, Intel ${ }^{\circledR}$ Core $^{\mathrm{TM}}$ i3 dan 64 bit Windows 8.1 OS. Seluruh unsur yang telah dibuat dalam proses desain di atas kemudian diolah menjadi satu kesatuan sistem aplikasi sederhana menggunakan software IDE Official Android Studio. Dalam penelitian ini telah tercipta sebuah produk media pembelajaran seni musik berbasis Android yang dinamakan Musicroid. Unsur-unsur yang ada di dalamnya yaitu Splash Screen, Menu Utama (Home), Sejarah Musik, Materi Notasi, Kuis Chord Theory dan Pengetahuan Umum Musik, Chord Theory, Video Lesson, Info Aplikasi dan Credit Apps.

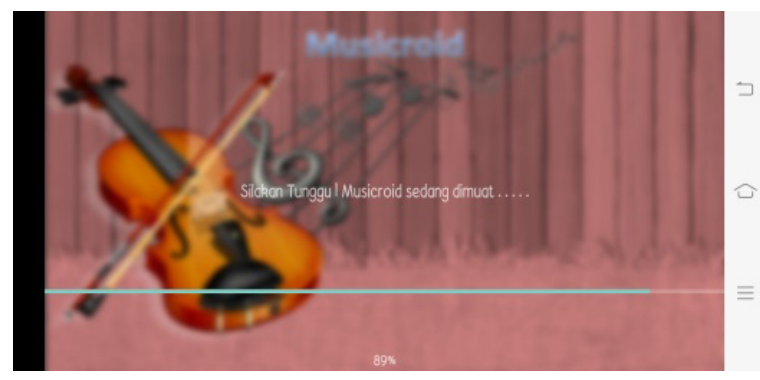

Gambar 1 Splash Screen

Gambar 1. Splash screen, memunculkan logo dan nama aplikasi "Musicroid".

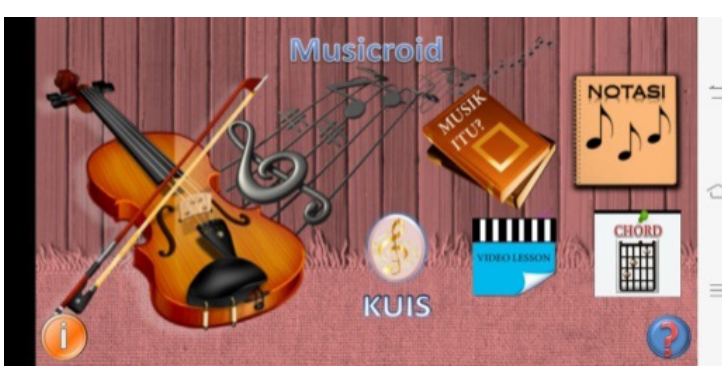

Gambar 2 Menu Utama

Gambar 2. Menu utama (Home Screen) merupakan sebuah peta konsep dari materi yang tersedia di aplikasi ini.

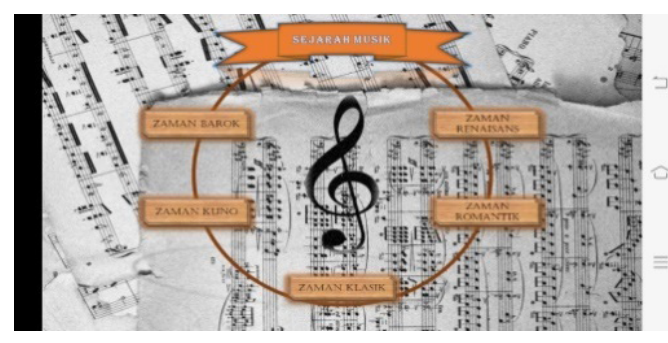

Gambar 3 Sejarah Musik

Gambar 3 menampilkan sejarah musik. Dalam menu sejarah musik terdapat beberapa pilihan sejarah apa yang akan dipelajari mulai dari zaman barok, renaisans, kuno, romantic, dan klasik. Gambar 4 menampilkan halaman yang membawa pengguna untuk belajar notasi balok sederhana.

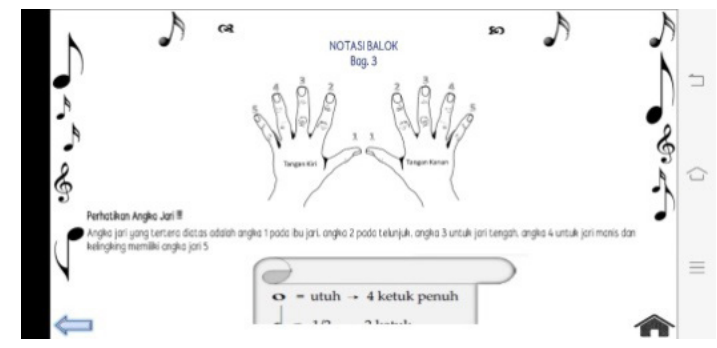

Gambar 4. Notasi Balok 


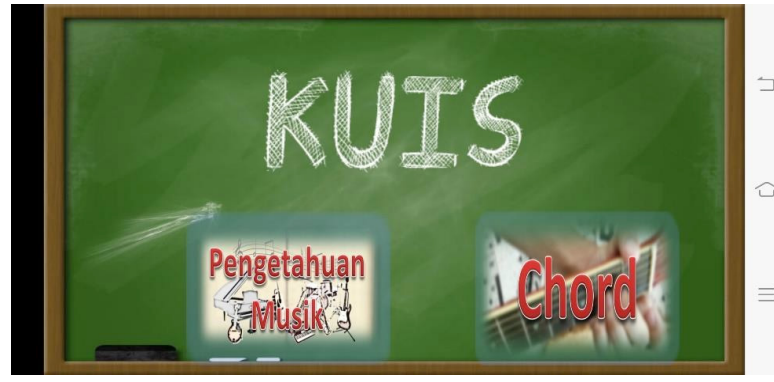

Gambar 5a. Pilihan Kuis Pengetahuan Musik dan Chord

Gambar 5 merupakan halaman kuis yang terdiri dari kuis chord dan pengetahuan umum musik. Kuis pengetahuan umum (Gambar 6a), siswa langsung dihadapkan pada pertanyaan-pertanyaan yang mencakup teori musik dasar dan hasilnya dapat dilihat ketika semua pertanyaan telah dijawab maka akan dibawa pada halaman hasil kuisnya. Sedangkan kuis chord digunakan untuk mengasah pemahaman users dari materi yang telah dipelajari (Gambar 6b). Kuis chord ini sangat mudah digunakan karena siswa hanya akan dihadapkan pada soal nama chord dan memilih jawaban diagram chord yang benar di antara tiga alternatif jawaban. Pada halaman ini juga benar dan salahnya jawaban yang dipilih dapat diketahui dari suara yang dimainkan oleh aplikasi dan terdapat papan nilai diatas layout.

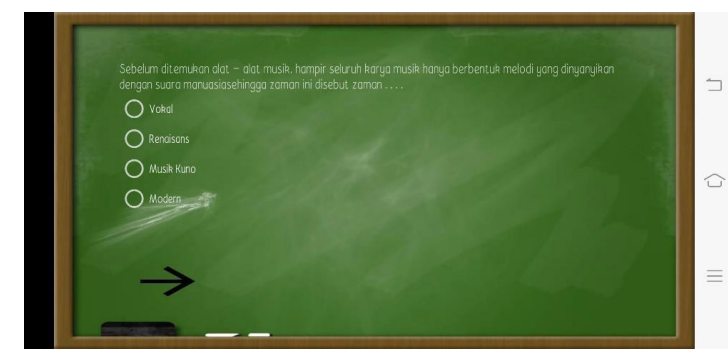

Gambar 6a. Kuis Pengetahuan Musik

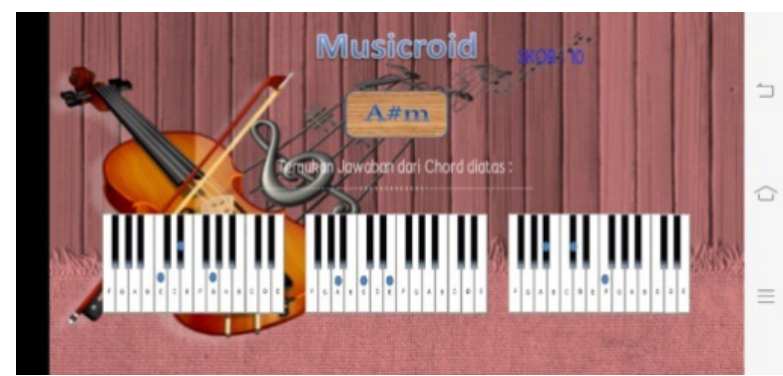

Gambar 6b. Kuis Chord Piano

Halaman selanjutnya adalah tampilan chord (Gambar 7), di sini terdapat materi tentang chord yaitu Chord Piano Mayor, Chord Piano Minor, Chord Gitar Mayor, dan Chord Gitar Minor. Pilihan menu dapat dengan mudah di-scroll ke kanan dan kiri.

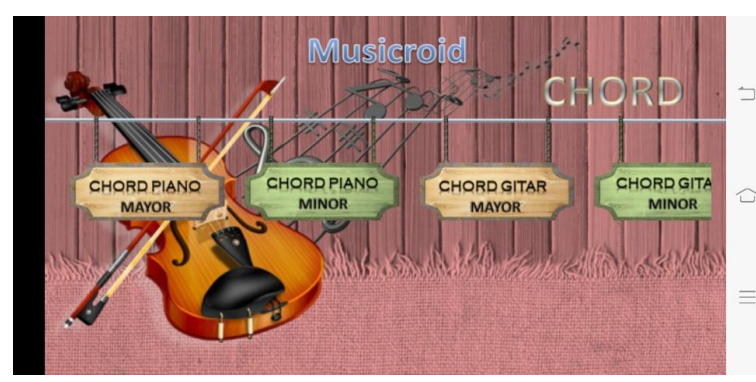

Gambar 7. Menu Chord

Gambar 8 menampilkan Chord Piano Theory. Halaman ini terdapat materi mengenai chord piano mayor dan minor dasar dengan navigasi menu disamping kiri menggunakan ScrollView.

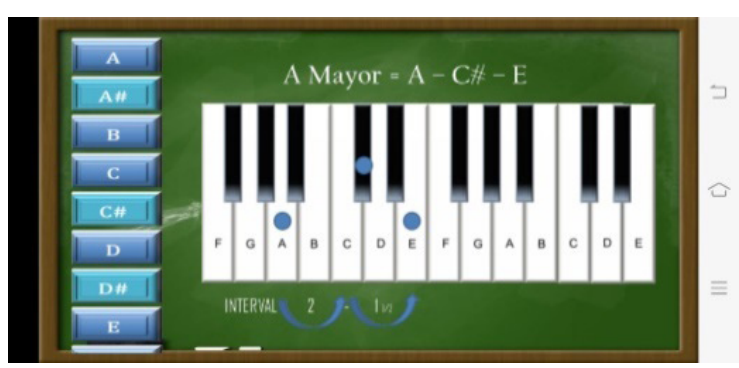

Gambar 8. Chord Piano Theory

Chord Gitar ditampilkan pada Gambar 9. Tidak ada perbedaan secara teknis dengan chord piano, namun hanya akan dibedakan secara muatan materi di dalam halaman ini. Yaitu memuat tentang chord gitar mayor dan juga chord minor dasar

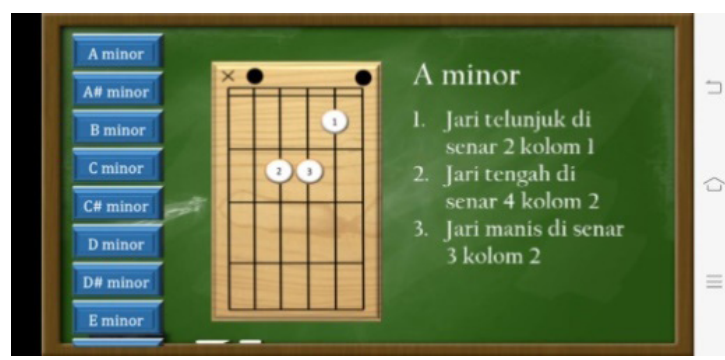

Gambar 9. Chord Gitar

Tersedianya beberapa materi terlihat pada Gambar 10 , berupa video yang terintegrasikan langsung dengan channel Youtube dari pengembang dan konten dibuat sendiri tanpa menggunakan konten orang lain di dalamnya.

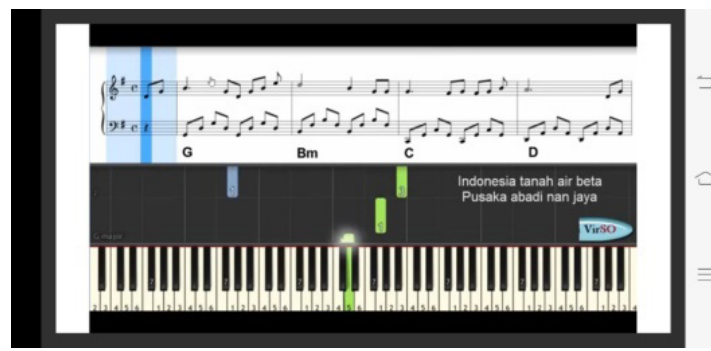

Gambar 10. Video Lesson 


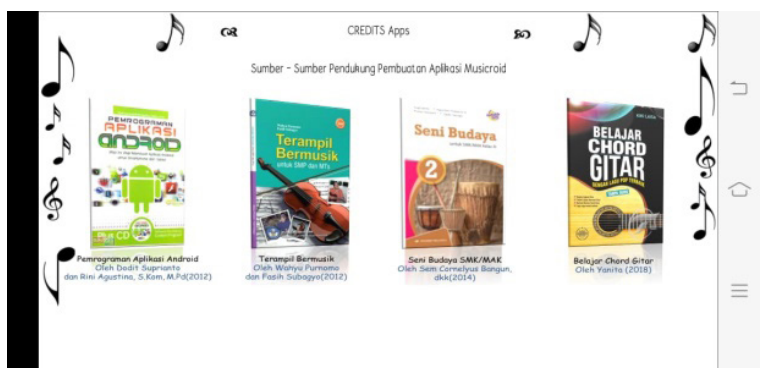

Halaman terakhir adalah halaman informasi yang menunjukkan dari mana aplikasi ini dikembangkan dan siapa saja yang terlibat di dalamnya (Gambar 11).

\section{a. Analisis Data}

Analisis data adalah perangkat uji coba aplikasi media kepada ahli materi, ahli media, dan siswa. Tabel 6 menunjukkan hasil uji validasi ahli materi, Tabel 7 hasil media, dan Tabel 8 hasil uji kelayakan usability.

Gambar 11. Info dan Credits Aplikasi

Tabel 6. Hasil Uji Validasi Ahli Materi

\begin{tabular}{|c|c|c|c|c|}
\hline Aspek & Indikator & Nilai & Rata-Rata & Kategori \\
\hline \multirow{3}{*}{ Kebenaran Konsep } & Kejelasan tujuan pembelajaran & 9,00 & 4,50 & Sangat Layak \\
\hline & $\begin{array}{l}\text { Kebenaran materi ditinjau dari aspek } \\
\text { keilmuan }\end{array}$ & 10,00 & 5,00 & Sangat Layak \\
\hline & Penggunaan bahasa & 9,00 & 4,50 & Sangat Layak \\
\hline \multirow{3}{*}{ Penyusunan Materi } & Kesesuaian materi & 8,00 & 4,00 & Layak \\
\hline & Kontekstualitas & 9,00 & 4,50 & Sangat Layak \\
\hline & $\begin{array}{l}\text { Kelengkapan bahan pendukung } \\
\text { materi }\end{array}$ & 10,00 & 5,00 & Sangat Layak \\
\hline \multirow{3}{*}{ Potensi Keterlaksanaan } & Kemudahan materi untuk dipahami & 9,00 & 4,50 & Sangat Layak \\
\hline & Alur logika yang jelas & 10,00 & 5,00 & Sangat Layak \\
\hline & Interaktivitas & 9,00 & 4,50 & Sangat Layak \\
\hline \multicolumn{2}{|l|}{ Rata-Rata Keseluruhan } & & 4,6 & Sangat Layak \\
\hline
\end{tabular}

Tabel 7. Hasil Uji Validasi Ahli Media

\begin{tabular}{clccc}
\hline \multicolumn{1}{c}{ Aspek } & \multicolumn{1}{c}{ Indikator } & Nilai & Rata-rata & Kategori \\
\hline & Efisiensi panduan & 8,00 & 4,00 & Layak \\
& Kehandalan panduan (reliable $)$ & 8,00 & 4,00 & Layak \\
Rekayasa Perangkat Lunak & Kemudahan penggunaan panduan & 9,00 & 4,50 & Sangat Layak \\
& Ketepatan pemilihan software/tool untuk & 9,00 & 4,50 & Sangat Layak \\
& mengembangkan panduan & 9,00 & 4,50 & Sangat Layak \\
& Pemaketan program panduan & 9,00 & 4,50 & Sangat Layak \\
& Komunikatif & 9,00 & 4,50 & Sangat Layak \\
& Kreatif dalam gagasan ide & 9,00 & 4,50 & Layak \\
& Tampilan sederhana dan memikat & 9,00 & Layak \\
& Penggunaan visual & 8,00 & 4,00 & Sangat Layak \\
& Pemilihan warna & 8,00 & 4,00 & Sangat Layak \\
\hline Romunikasi Visual & Pemilihan jenis huruf & 9,00 & 4,50 & Sangat Layak \\
\hline
\end{tabular}


Berdasarkan hasil uji validasi oleh ahli materi, didapatkan nilai rata-rata 4,6 dengan kategori Sangat Layak sehingga dapat diambil kesimpulan bahwa aplikasi musicroid sebagai media pembelajaran seni music di SMKN 2 Ponorogo Sangat Layak.

Dari hasil uji validasi yang dilakukan oleh ahli media (Tabel 7), rata-rata secara keseluruhan adalah 4,3 dan masuk dalam kategori Sangat Layak. Berdasarkan hasil uji validasi tersebut, maka dapat disimpulkan bahwa aplikasi musicroid sebagai media pembelajaran seni musik di SMKN 2 Ponorogo Sangat Layak.

Tabel 8. Hasil Uji Kelayakan Usability

\begin{tabular}{ccc}
\hline Responden & Rata-Rata & Kategori \\
\hline R 1 & 6,8 & Sangat Layak \\
R 2 & 6,3 & Sangat Layak \\
R 3 & 5,8 & Sangat Layak \\
R 4 & 5,5 & Layak \\
R 5 & 5,2 & Layak \\
R 6 & 6,7 & Sangat Layak \\
R 7 & 6,0 & Sangat Layak \\
R 8 & 5,8 & Sangat Layak \\
R 9 & 6,8 & Sangat Layak \\
R 10 & 4,7 & Layak \\
R 11 & 5,2 & Layak \\
R 12 & 4,2 & Layak \\
R 13 & 4,1 & Layak \\
R 14 & 6,0 & Sangat Layak \\
R 15 & 6,8 & Sangat Layak \\
R 16 & 6,7 & Sangat Layak \\
R 17 & 6,2 & Sangat Layak \\
R 18 & 6,8 & Sangat Layak \\
R 19 & 6,0 & Sangat Layak \\
R 20 & 6,0 & Sangat Layak \\
\hline Rata - Rata & $117,6 / 20=$ & Sangat Layak \\
Keseluruhan & 5,88 & \\
\hline
\end{tabular}

Hasil dari uji faktor usability (Tabel 8), secara keseluruhan rata-ratanya mencapai angka 5,88 sehingga termasuk ke dalam kategori Sangat Layak. Musicroid telah memenuhi uji aspek kelayakan bagi pengguna melalui computer system usability questionnare yang dikembangkan J.R Lewis ini, maka aplikasi Musicroid sebagai media pembelajaran seni musik di SMKN 2 Ponorogo dapat digunakan sebagai media dalam pembelajaran.

\section{Kesimpulan} adalah:

Kesimpulan dari penelitian yang telah dilakukan

Pengembangan aplikasi Musicroid sebagai media pembelajaran seni musik di SMKN 2 Ponorogo menggunakan model pengembangan ADDIE yang dapat dijabarkan mulai dari Analysis (Analisis), Design
(Desain), Development (Pengembangan), Implementation (Implementasi), dan Evaluation (Evaluasi). Dalam penelitian ini, evaluasi dilakukan dalam tahap desain dan pengembangan sebab uji kelayakan dalam produk ini masuk dalam kategori sangat layak. Sehingga tidak memerlukan perbaikan yang berarti.

Kelayakan aplikasi Musicroid berdasarkan hasil uji validasi ahli materi menunjukkan nilai 4,6 dan masuk dalam kategori sangat layak. Kelayakan aplikasi Musicroid berdasarkan hasil uji validasi ahli media mendapatkan nilai 4,3 dan masuk dalam kategori sangat layak. Aplikasi Musicroid mendapat respons yang positif dari para penggunanya terutama siswa di SMKN 2 Ponorogo dan dalam uji kelayakan faktor usability memperoleh nilai 5,8 yang dapat dikategorikan sangat layak sebagai media pembelajaran seni musik.

\section{Daftar Pustaka}

[1] P. A. Sembodo, "Pemanfaatan Media Audio Visual Pada Pembelajaran Seni Musik Di SMP Negeri 5: Analisis Proses Dan Hasil Belajar," Semarang, 2015.

[2] I. S. Nugraha, K. I. Satoto, and K. T. Martono, "Pemanfaatan Augmented Reality Untuk Pembelajaran Pengenalan Alat Musik Piano," J. Teknol. dan Sist. Komput., vol. 2, no. 1, pp. 62-70, 2019.

[3] I. Rizkiansyah and T. Sukardiyono, "Pengembangan Aplikasi Pembelajaran Interaktif Teknik Bermain Piano Berbasis Multimediadi Lembaga Kursus Musik 'Ethnictro' Yogyakarta," Yogyakarta, 2013.

[4] A. Mukherjee and A. Mishra, "A project based on Android OS,” Bokaro, India, 2016.

[5] W. Slany, "Catroid: a mobile visual programming system for children," ... Conf. Interact. Des. Child., pp. 300-303, 2012.

[6] W. Slany, "A mobile visual programming system for Android smartphones and tablets," in Proceedings of IEEE Symposium on Visual Languages and Human-Centric Computing, VL/HCC, 2012, pp. 265-266.

[7] E. Rugut and L. N. Makewa, "Utilisation of Educational Media in Teaching and Learning of History and Government in Selected Secondary Schools in Kenya," IOSR J. Humanit. Soc. Sci., vol. 21, no. 09, pp. 46-55, 2016.

[8] A. A. Sakat, M. Z. Mohd Zin, R. Muhamad, A. Ahmad, N. A. Ahmad, and M. A. Kasmo, "Educational Technology Media Method in Teaching and Learning Progress," Am. J. Appl. Sci., vol. 9, no. 6, pp. 874-878, 2012.

[9] M. A. Ramdhani and H. Muhammadiyah, "The Criteria of Learning Media Selection for Character 
Education in Higher Education," in Proceeding International Conference of Islamic Education: Reforms, Prospects and Challenges Faculty of Tarbiyah and Teaching Training, Maulana Malik Ibrahim State Islamic University, Malang, 2015, no. December 2015, pp. 174-182.

[10] Nurdyansyah and E. F. Fahyuni, Inovasi Model Pembelajaran. Sidoarjo: Nizamial Learning Center, 2016.

[11] D. Suprianto and R. Agustina, Pemrograman Aplikasi Android. Yogyakarta: MediaKom, 2012.

[12] N. Safaat H, Pemrograman Aplikasi Mobile Smartphone dan Tablet PC Berbasis Android. Bandung: Informatika, 2012.

[13] R. M. Branch and T. A. Dousay, Survey of Instructional Design Models 5th ed. Bloomington, Indiana: Association for Educational Communications and Technology, 2015.

[14] R. M. Branch, Instructional Design: The ADDIE Approach, 2010th Edi. Springer, 2009.

[15] A. Alcid, L. B. Bandril, A. De Guzman, and L. J. Lopez, "Analysis, Design, Development, Implementation, and Evaluation of a Serious Game Designed to Inform Users on Environmental Issues," Int. J. Comput. Sci. Res., vol. 1, no. 1, pp. 11-23, 2017.

[16] N. Aldoobie, "ADDIE Model," Am. Int. J. Contemp. Res., vol. 5, no. 6, pp. 68-72, 2015.

[17] W. Purnomo and F. Subagyo, Terampil Bermusik. Solo: Pusat Perbukuan Kementerian Pendidikan Nasional, 2010.

[18] S. Creedy, "Chords for Piano and Guitar."
[19] M. Phillips and J. Chappell, Guitar For Dummies. Indianapolis: Wiley Pub, Inc, 2006.

[20] M. Rogers and M. Norman, Guitar Method. JW Productions, 2006.

[21] M. Kennedy and N. G. Academy, Guitar Chords For Beginners. National Guitar Academy.

[22] M. Muttaqin and Kustap, Seni Musik Klasik, 2nd ed. Direktorat Pembinaan Sekolah Menengah Kejuruan, 2008.

[23] S. Hadi, Sumasno Hadi - Humanisme.pdf, Fisrt. Yogyakarta: Dandra Kreatif, 2015.

[24] D. Taher, Sejarah Musik 2. Pendidikan Seni Musik Universitas Negeri Yogyakarta Fakultas Bahasa Dan Seni, 2009.

[25] A. Sudijono, Pengantar evaluasi pendidikan, 1st ed, 12. Jakarta: Raja Grafindo Persada (Rajawali Pers), 2011.

[26] S. Andrianita, "Pengembangan Dan Analisis Kualitas Aplikasi Panduan Shalat Jenazah Pada Handphone Berbasis Android,” Yogyakarta, 2015.

[27] B. B. Agarwal, S. P. Tayal, and M. Gupta, Software Engineering \& Testing, Computer S. Sudbury, Massachusetts: Jones and Bartlett Publishers, 2010.

[28] J. R. Lewis, "IBM Computer Usability Satisfaction Questionnaires: Psychometric Evaluation and Instructions for Use," Int. J. Hum. Comput. Interact., vol. 7, no. 1, pp. 57-78, 1995.

[29] J. R. Lewis, "Computer System Usability Questionnaire," Int. J. Hum. Comput. Interact., vol. 7, no. 1, pp. 57-78, 1995. 